\title{
Effects of modified atmosphere packaging (MAP) and Aloe vera treatments on quality characteristics of cornelian cherry fruits during cold storage
}

\author{
Burhan ÖZTÜRK ${ }^{1}$, Erdal AĞLAR ${ }^{2}$
}

${ }^{1}$ Ordu University, Faculty of Agriculture, Department of Horticulture, Altınordu, Ordu

${ }_{2}^{2}$ Sivas Cumhuriyet University, Sușehri Timur Karabal Vocational School, Sivas

Alınış tarihi: 7 Eylül 2018, Kabul tarihi: 20 Kasım 2018

Sorumlu yazar: Erdal AĞLAR, e-posta: erdalaglar@gmail.com

\begin{abstract}
This study was carried out to determine the effects of MAP and Aloe vera (AV) treatments on quality characteristics of cornelian cherry (Cornus mas L.) during cold storage. In the study, control, MAP-1, MAP-2 and AV were determined as treatments. Fruit was stored at $0 \pm 0.5^{\circ} \mathrm{C}$ and $90 \pm 5 \%$ relative humidity. The measurements and analyses were performed on 7, 14 and $21^{\text {st }}$ day. During the cold storage, weight losses were significantly retarded with AV and MAP treatments. Higher firmness was measured from MAP and AV-treated fruits as compared to the control. Lower $\mathrm{L}^{*}$ and hue angle values in MAP and AV treatments were measured than the control, whereas a higher chroma value was determined. At the end of cold storage, the lowest and the highest respiration rate respectively was obtained from MAP-1 and AV treatments. Also, higher soluble solids content (SSC), titratable acidity (except for MAP-2) and vitamin $\mathrm{C}$ were obtained from $\mathrm{AV}$ and MAP treatments than the control. As a result, it revealed that AV and MAP treatments could be used as a tool to maintain quality of cornelian cherry fruits during cold storage.
\end{abstract}

Key words: Aloe vera, Cornus mas L., firmness, weight loss
Soğukta muhafaza süresince modifiye atmosfer paketleme (MAP) ve Aloe vera uygulamalarının kızılcık meyvelerinin kalite özellikleri üzerine etkileri

\section{Öz}

$\mathrm{Bu}$ çalışma, soğukta muhafaza süresince, kızılcık (Cornus mas L.) meyvesinin kalite özellikleri üzerine MAP ve Aloe vera (AV) uygulamalarının etkilerini belirlemek amacıyla yürütülmüștür. Araştırmada kontrol, MAP-1, MAP-2 ve AV olarak 4 uygulama belirlenmiştir. Meyveler, $0 \pm 0.5^{\circ} \mathrm{C}^{\prime}$ de ve \% $90 \pm 5$ nispi nem koşullarında muhafaza edilmiştir. Ölçüm ve analizler 7,14 ve 21. günlerde yürütülmüştür. Soğuk depolama süresince, MAP ve AV uygulamaları ile ağırlık kaybı önemli derecede geciktirilmiştir. MAP ve AV uygulanmış meyvelerden kontrole kıyasla daha yüksek sertlik ölçülmüştür. Yine MAP ve AV uygulamalarından, daha düşük $L^{*}$ ve hue açısı değeri, aksine daha yüksek kroma değeri ölçülmüştür. Soğukta muhafazanın sonunda, en düşük solunum MAP-1 uygulamasından, en yüksek ise AV uygulamasından ölçülmüştür. Aynı zamanda MAP ve AV uygulamalarından, kontrole kıyasla daha yüksek suda çözünür kuru madde (SÇKM), titre edilebilir asitlik (MAP-2 hariç) ve $C$ vitamini elde edilmiştir. Sonuç olarak MAP ve AV uygulamalarının kızılcık meyvesinin soğukta muahafaza süresince kalite özelliklerini korumak için bir araç olarak kullanılabileceği açığa çıkarılmıştır.

Anahtar kelimeler: Aloe vera, Cornus mas L., sertlik, ağırlık kaybı 


\section{Introduction}

Cornelian cherry is a fruit species used by humans due to its anti-inflammatory properties since ancient times. In recent years, cornelian cherry fruits, which attracted the attention of consumers due to its unusual taste and high antioxidant content, are consumed fresh. Cornelian cherry contains many active compounds such as vitamin $\mathrm{C}$, organic acids, pectin, phenolic acids and flavonoids (Kucharska et al., 2011; Kucharska, 2012). Cornelian cherry is used in modern medicine due to its anti-inflammatory attributes (Dinda et al., 2016). With the understanding of the positive effects on human health, there is an increase in cornelian cherry consumption. However, the postharvest life in the cornelian cherry is relatively short, due to its fruit characteristics. This limits the marketing period for fresh consumption, ultimately the amount of consumption. Potential storage of fruits without any or significant losses in quality attributes is a critical issue influencing marketing period of the fruits. Therefore, it is quite significant in cornelian cherries to prolong post-harvest life of the fruits with minimum losses in quality attributes. After the harvest and during cold storage, the chemical and physical changes in fruits and vegetables, which result in losses in nutritional quality, occur (Asghari et al., 2013). In most fruit species, to prevent these adverse effects caused by postharvest factors, postharvest technologies such as modified atmosphere packaging and AV are commonly used (Lurie, 2006). Modified atmosphere treatments restrict gas exchange through packaging material and thus recess metabolic activities of the products. In brief, they create a modified atmosphere within the packaging material. The modified atmosphere in packages directly influences respiration rates of the fruits and vegetables, reduce ethylene synthesis and ethylene-sensitivity of the fruits and retard ripening process (Cantin et al., 2008).

$\mathrm{AV}$ is an environment friendly and low cost coating material for prolonging the shelf life of horticultural crops under ordinary storage condition. The coating materials such as chitosan, 'Parka' and AV, which is edible, are used to maintain quality and nutritional value, and to provide market safety, in most foods. Edible coatings provide moisture and gas barrier on the surface of the product. Thus the loss of moisture is reduced and gas exchange is controlled. In conclusion, the quality losses occured in the product have decreased and have slow down the respiration and delay deterioration in the fruits. The gas barrier on the surface of fruit can be retarded the enzymatic oxidation and delayed browning discoloration and texture softening in fruit during storage. It has been determined that MAP and AV applications in fruit species such as sweet cherry (Valero et al., 2014), table grape (Serrano et al., 2006) and nectarines (Navarro et al., 2011) have reduced fruit quality losses of the postharvest. However, there are no studies on post harvest MAP and AV applications in cornelian cherry.

The aim of research was to determine the effects of MAP and AV treatments on fruit quality characteristics of cornelian cherry (Cornus mas L.) during cold storage.

\section{Material and methods}

\section{Plant material}

The study was carried out in a commercial orchard located in Vakfıkebir in 2016. At the maturity stage, cornelian cherry (Cornus mas L.) fruits with uniform shape and size and free from visual symptoms of any disease were hand-harvested. The fruits harvested were transported by frigorific vehicles, which has 10 ${ }^{\circ} \mathrm{C}$ and $80 \% \mathrm{RH}$, to postharvest physiology laboratory of Horticulture Department of Ordu University.

\section{Experimental design}

About $5 \mathrm{~kg}$ fruit for each treatment were harvested randomly. 150 fruits were used to determine quality characteristics at harvest. For cold storage, treatments were designed as control, MAP-1 (17 $\mu \mathrm{m}$ LDPE), MAP-2 (23 $\mu \mathrm{m}$ LDPE) and AV. For AV treatments, fruit was dipped within $66 \%$ AV gel for 5 s. Then fruit was dried in room conditions. Fruit was divided to 9 tray with $500 \mathrm{~g}$ for each treatment. For each analysis period, 3 trays were used, namely for each replicate was used 1 tray. Also the fruit was exposed to the pre-cooling (by cold air during $24 \mathrm{~h}$ at $4 \pm 0.5^{\circ} \mathrm{C}$ and $90 \pm 5 \% \mathrm{RH}$ ) for MAP treatment. Fruits were stored at $0 \pm 0.5^{\circ} \mathrm{C}$ and $90 \pm 5 \% \mathrm{RH}$ for 7,14 and 21 days and at the end of each storage period, analyzes were performed.

\section{Weight loss, respiration rate and firmness}

The weights of the fruits were determined by using a digital scale $( \pm 0.01$ g) (Radvag PS $4500 / C / 1$, Poland), and weight loss was expressed as percent (\%). It was determined by recording the results between the initial and final weights of each replicate during cold storage. Respiration rate and 
firmness were determined accordance with Ozturk et al. (2018).

\section{SSC, titratable acidity and vitamin C}

In order to determine the values of soluble solids content, titratable acidity (TA) and vitamin C, for each replicate, firstly the stones of the fruits (30 fruits) were removed, and the extracts of these fruits were obtained with an electrical fruit juice extractor (HR1855/70, Philips, Turkey). SSC (\%), TA (g malic acid $100 \mathrm{~g}^{-1}$ ) and vitamin $\mathrm{C}$ content (mg $100 \mathrm{~g}^{-1}$ ) was analyzed in accordance with Ozturk et al. (2018).

\section{Color characteristics}

Color values ( $\mathrm{L}^{*}$, chroma and hue angle) were determined by measuring at opposite sides of each fruit with a colorimeter (Konica-Minolta, model CR400, Japan) in 10 fruits for each replication. 3-D color space was defined with the aid of $\mathrm{L}^{*}, \mathrm{a}^{*}$ and $\mathrm{b}^{*}$ values. Equations in parenthesis were used to calculate chroma $\left[\mathrm{C}^{*}=\left(\mathrm{a}^{*}+\mathrm{b}^{* 2}\right)^{1 / 2}\right]$ and hue angle $\left(h^{\circ}=\tan ^{-1} b^{*} / a^{*}\right)$.

\section{Statistical analysis}

The data were analyzed with ANOVA by using SAS Version 9.1 (SAS Institute Inc., Cary, NC, USA) software. The significance level between the averages was made by using the Tukey's test. All analyzes were performed in the SAS package program.

\section{Results and discussion}

\section{Weight loss}

Compared to the control treatment, it was determined that both MAP and AV treatments reduced weight loss during storage, but the influence of MAP treatment on weight loss was higher than AV treatment (Table 1). MAP has the properties, which protect the fruit from external factors and reduces moisture loss on fruits during cold storage. It is thought that these properties of MAP are effective on our study results. It was determined that MAP application delayed the weight losses during storage in sweet cherry (Aglar et al., 2017) and plum (Peano et al., 2010; Kaynaş et al., 2010; Guillen et al., 2013).

Edible coatings such as AV provides moisture barrier on the surface of produce for reducing the problem of moisture loss causing weight loss and changes in texture, flavor, and appearance of the fruit. AV gel had reduced weight loss for coated oranges (Arowora et al., 2013), berry (Valverde et al., 2005) and grape (Asghari et al., 2013).

\section{Respiration rate}

The most significant factor that determines the postharvest life is the rate of respiration of the fruit. Therefore, the main goal in storage is to reduce the rate of respiration of the fruit. The packaging techniques such as MAP, which controls the gas atmosphere around the fruit, and coating methods such as $\mathrm{AV}$, which reduces the gas permeability of the fruit, are successfully applied to control the respiration rate. In our study, it was determined that an increase in the respiration rate occurred in proportion to the storage period. At the end of the storage, MAP-1 treatment has decreased the respiration rates, whereas the respiration rates of the fruits treated-MAP-2 and AV treatments were higher than the respiration rates of control fruits (Table 1). Moreira et al. (2011) determined that AV gel based edible coatings have controlled respiration rate in fruits such as sweet cherry, table grapes and nectarines. Edible coatings as $\mathrm{AV}$ provides a gas barrier for control gas exchange between the fresh produce and its surrounding atmosphere, this would slow down the respiration and delay deterioration in oranges (Arowora et al., 2013), berry (Valverde et al., 2005) and grape (Asghari et al., 2013).

\section{Fruit firmness}

Fruit firmness is one of the significant quality parameters in determining the time of the harvest for many fruit species. Fruit firmness is often determined for scientific purposes and provides the information needed for resistance to food damage and storage during marketing and cold storage (Valero et al., 2007). Due to the effect of enzyme activity on the cell wall, the structural and chemical changes that take place in the carbohydrates in the cell wall cause the softening in the fruit (Fischer and Bennett, 1991). With MAP and low temperature treatments, enzyme activity and ethylene biosynthesis are reduced (Lazan et al., 1993), firmness is maintained. Again, Erkan and Eski (2012) reported that MAP treatment delayed the softening of the fruit at the cold storage. In this study, as compared to control, it has been recorded that MAP treated-fruits had higher fruit firmness values during storage. However, there was no statistical difference between MAP treatments in terms of effect on fruit softening (Table 1). In accordance with results of study, it has been reported that MAP treatment was effective in maintaining fruit firmness in sweet cherry (Aglar et al., 2017) and plum (Kaynaş et al., 2010). 
The fruit softening, which is one of the most significant criteria in storage, can be delayed by AV treatment in peach, plum, (Guillen et al., 2013; Valero et al., 2014), apple (Ergun and Satici, 2012), nectarine (Navarro et al., 2011), table grape (Serrano et al., 2006). Zapata et al. (2013) report that AV, which has anti-fungal and gel properties, can be used to maintain fruit qualities in pre and post-harvest. Consistent with the results of the previous study, in this study, it was determined that AV treatment has a fruit-firmness-retarding effect during storage and there is no difference between MAP and AV treatments in terms of the effect on fruit firmness values (Table 1).

Table 1. Effects of MAP and AV treatments on weight loss, respiration rate and firmness of cornelian cherry fruits

\begin{tabular}{|c|c|c|c|c|}
\hline \multirow{3}{*}{ Treatments } & \multicolumn{4}{|c|}{ Storage period (days) } \\
\hline & Harvest & 7 day & 14 day & 21 day \\
\hline & \multicolumn{4}{|c|}{ Weight loss (\%) } \\
\hline Control & - & $2.03 \mathrm{a}$ & $3.92 \mathrm{a}$ & $5.57 \mathrm{a}$ \\
\hline Aloe vera & - & $1.12 \mathrm{~b}$ & $1.19 \mathrm{~b}$ & $1.35 \mathrm{~b}$ \\
\hline MAP-1 & - & $0.12 \mathrm{c}$ & $0.31 \mathrm{c}$ & $0.44 \mathrm{c}$ \\
\hline \multirow[t]{2}{*}{ MAP-2 } & - & $0.13 \mathrm{c}$ & $0.27 \mathrm{c}$ & $0.39 \mathrm{c}$ \\
\hline & \multicolumn{4}{|c|}{ Respiration rate $\left(\mathrm{mL} \mathrm{CO}_{2} \mathrm{~kg}^{-1} \mathrm{~h}^{-1}\right)$} \\
\hline Control & 20.73 & $48.15 \mathrm{~b}$ & $64.08 \mathrm{~b}$ & $68.00 \mathrm{~b}$ \\
\hline Aloe vera & 20.73 & $39.49 \mathrm{c}$ & $75.18 \mathrm{a}$ & $108.11 \mathrm{a}$ \\
\hline MAP-1 & 20.73 & $57.12 \mathrm{a}$ & $57.31 \mathrm{c}$ & $58.91 \mathrm{c}$ \\
\hline \multirow[t]{2}{*}{ MAP-2 } & 20.73 & $64.48 \mathrm{a}$ & $78.04 \mathrm{a}$ & $70.93 \mathrm{~b}$ \\
\hline & \multicolumn{4}{|c|}{ Fruit Firmness (N) } \\
\hline Control & 77.72 & $63.00 \mathrm{~b}$ & $56.65 \mathrm{~b}$ & $52.60 \mathrm{~b}$ \\
\hline Aloe vera & 77.72 & $68.85 \mathrm{a}$ & $59.95 \mathrm{a}$ & $57.95 \mathrm{a}$ \\
\hline MAP-1 & 77.72 & $72.30 \mathrm{a}$ & $61.00 \mathrm{a}$ & $56.30 \mathrm{a}$ \\
\hline MAP-2 & 77.72 & $69.30 \mathrm{a}$ & $59.65 \mathrm{a}$ & $57.95 \mathrm{a}$ \\
\hline
\end{tabular}

Means in columns with the same letter do not differ according to Tukey's test at $\mathrm{P}<0.05$.

\section{SSC, TA and vitamin C}

During the storage, SSC increased, but vitamin $\mathrm{C}$ and TA content decreased. In terms of the SSC, it was determined that there was not a statistically significant difference between MAP 2 and control on $7^{\text {th }}$ day of storage, and MAP-1 and AV had higher SSC values than the other two treatments. However, at the end of 14 and $21^{\text {st }}$ days of storage, the lowest SSC value was recorded in the control, while there was no statistical difference between the other three treatments. It was found that the effect of MAP-1 and $\mathrm{AV}$ treatments was significant in maintaining of the TA, but there was the difference between MAP-2 and control on only $7^{\text {th }}$ day of storage. The highest titratable acidity value at the end of storage had been recorded in the fruits treated with AV. It has been determined that vitamin $C$ loss during the storage period was retarded by MAP and AV treatments. While the vitamin C recorded as $259 \mathrm{mg}^{100 \mathrm{~g}^{-1} \text { at }}$

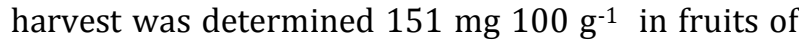
control treatment at the end of storage, vitamin $\mathrm{C}$ value in fruits of AV treatment has been determined

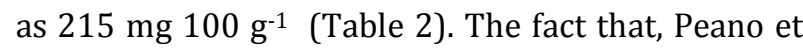
al. (2010) determined that during cold storage the content of SSC has increased, and the loss of acidity in MAP-treated fruits was lower. However, Cantin et al. (2008) reported that MAP treatment does not have any effects on SSC content, and cause a decrease on titratable acidity. Khan and Sing, (2008) determined the SSC and titratable acidity content in MAP-treated fruits are lower, whereas Kaynas et al. (2010) obtained higher SSC and titratable acidity values in MAP treatments. Again, Sottile et al. (2013) reported that with MAP treatment on plum, during storage, the amount of SSC increased and the content of titratable acidity decreased. The decrease in vitamin $\mathrm{C}$ during storage can be attributed to the oxygen released in ascorbic acid, conversion dehydroascorbic acid conversion (Sumnu and Bayindirli, 1995). Singh and Rao (2005) reported that MAP treatment has an effect maintaining on amount of vitamin C in papaya, and MAP treatment on broccoli reduced the loss of vitamin (Serrano et al., 2006). In our study, it was determined that the AV treatment increased the amount of SSC, while it decreased titratable acidity and loss of Vitamin C (Table 2). In our study, sugars in control fruit may have been used more often in respiration. Therefore, lower SSC may be measured in control fruit. On $7^{\text {th }}$ days of the cold storage, TA sharply reduced. But in other measurement periods, decrease of TA was slower. At the beginning, as acidities in respiration was more used, decrease of acidity may be higher. 
Table 2. Effects of MAP and AV treatments on SSC, titratable acidity and vitamin C of cornelian cherry fruits

\begin{tabular}{|c|c|c|c|c|}
\hline \multirow{3}{*}{ Treatments } & \multicolumn{4}{|c|}{ Storage period (days) } \\
\hline & Harvest & 7 day & 14 day & 21 day \\
\hline & \multicolumn{4}{|c|}{ SSC (\%) } \\
\hline Control & 10.30 & $10.90 \mathrm{~b}$ & $10.70 \mathrm{c}$ & $11.15 \mathrm{~b}$ \\
\hline Aloe vera & 10.30 & $11.75 \mathrm{a}$ & $11.50 \mathrm{~b}$ & $12.70 \mathrm{a}$ \\
\hline MAP-1 & 10.30 & $11.80 \mathrm{a}$ & $12.60 \mathrm{a}$ & $12.65 \mathrm{a}$ \\
\hline \multirow[t]{2}{*}{ MAP-2 } & 10.30 & $10.70 \mathrm{~b}$ & $11.30 \mathrm{~b}$ & $12.50 \mathrm{a}$ \\
\hline & \multicolumn{4}{|c|}{ Titratable acidity ( $\mathrm{g}$ malic acid $100 \mathrm{~g}^{-1}$ ) } \\
\hline Control & 3.06 & $1.23 \mathrm{~b}$ & $1.18 \mathrm{~b}$ & $1.11 \mathrm{~b}$ \\
\hline Aloe vera & 3.06 & $1.42 \mathrm{a}$ & $1.36 \mathrm{a}$ & $1.31 \mathrm{a}$ \\
\hline MAP-1 & 3.06 & $1.41 \mathrm{a}$ & $1.41 \mathrm{a}$ & $1.29 \mathrm{a}$ \\
\hline \multirow[t]{2}{*}{ MAP-2 } & 3.06 & $1.45 \mathrm{a}$ & $1.23 \mathrm{~b}$ & $1.14 \mathrm{~b}$ \\
\hline & \multicolumn{4}{|c|}{ Vitamin C (mg $\left.100 \mathrm{~g}^{-1}\right)$} \\
\hline Control & 259 & $197 \mathrm{~b}$ & $154 \mathrm{~b}$ & $151 \mathrm{c}$ \\
\hline Aloe vera & 259 & $244 \mathrm{a}$ & $230 \mathrm{a}$ & $215 \mathrm{a}$ \\
\hline MAP-1 & 259 & $242 \mathrm{a}$ & $226 \mathrm{a}$ & $192 \mathrm{~b}$ \\
\hline MAP-2 & 259 & $249 \mathrm{a}$ & $220 \mathrm{a}$ & $198 \mathrm{~b}$ \\
\hline
\end{tabular}

Means in columns with the same letter do not differ according to Tukey's test at $\mathrm{P}<0.05$.

When similar studies were viewed, Guillen et al. (2013) reported that AV treatment on plum and peach did not affect the SSC value, but loss of TA during storage was lower. Valero et al. (2014) reported that $\mathrm{AV}$ in peach and cherry did not have any effect on SCC and acidity. Padmaja and Bosco (2014) recorded lower SSC and pH value, higher TA value in $\mathrm{AV}$ treated- fruits due to the delayed effect in fruit ripening of the $A V$ treatment. In the blueberry fruit, AV treatment decreased the titratable acidity during shelf life, while it increased SSC and pH (Vieira et al., 2016). Sogvar et al. (2016) determined that the $\mathrm{AV}$ treatment increased the contents of SSC and C vitamins in strawberry. Vitamin $\mathrm{C}$ is one of the most abundant existing antioxidants in fruits. At the end of cold storage and shelf life, the antioxidant capacity of the AV treatedfruits were better preserved, and the coating material treatment retarded quality losses occured during cold storage (Ochiki et al., 2014).

\section{Color characteristics}

Fruit color is one of the most significant quality characteristics, which effect marketing of the fruit. After the harvest, the increase in the chlorophyll breakdown, anthocyanin accumulation and the acceleration of the carotenoid synthesis depending on the increasing of the ethylene in the fruit increases the color change of the fruit. Slowing down of the fruit color change is a basic goal of preservation of postharvest quality. The color change in fruit is slow during cold storage, but it is accelerated during shelf life or at room temperature
(Guerra and Caquero, 2008). The coating technologies such as MAP and AV together with postharvest cold storage can be effective in slowing the color change of the fruit. As a matter of fact, Argenta et al. (2003) reported that the color development of plum fruits, which are maintained in atmosphere-altered cold environments, may be delayed. Carrillo-Lopez et al. (2000) reported that the modified atmosphere formed by the AV gel application delayed ethylene production, so chlorophyll breakdown, accumulation of anthocyanins and carotenoid synthesis in fruit slow down and ultimately the color change of the fruits slows down.

In our study, it has been determined that the AV treatment increased the chroma value, whereas decreased the $\mathrm{L}^{*}$ and hue angle values. It was determined that MAP treatment has got a significant effect on the color values, and the differences between MAP and AV treatments on the color values was not significant It was found that the MAPtreated fruit had higher chroma value and lower $\mathrm{L}$ and hue angle values than control fruits (Table 3).

As a matter of fact, Diaz-Mula et al. (2011) reported that MAP treatment has got a retarding effect on color change.

Giacalone and Chiabrando (2013) determined that, discoloration in MAP-treated fruit slow down after cold storage. In a cherry-based study it is stated that high $\mathrm{CO}_{2}$ and low $\mathrm{O}_{2}$ in the MAP can cause a decrease in $\mathrm{L}^{*}$, chroma and hue angle values (Remon et al., 2013). 
Table 3. Effects of MAP and AV treatments on $\mathrm{L}^{*}$, chroma and hue angle of cornelian cherry fruits

\begin{tabular}{|c|c|c|c|c|}
\hline \multirow{3}{*}{ Treatments } & \multicolumn{4}{|c|}{ Storage period (days) } \\
\hline & Harvest & 7 day & 14 day & 21 day \\
\hline & \multicolumn{4}{|c|}{$L^{*}$} \\
\hline Control & 39.21 & $51.42 \mathrm{a}$ & $46.10 \mathrm{a}$ & $47.81 \mathrm{a}$ \\
\hline Aloe vera & 39.21 & $43.63 \mathrm{~b}$ & $41.74 \mathrm{~b}$ & $42.91 \mathrm{~b}$ \\
\hline MAP-1 & 39.21 & $41.62 \mathrm{~b}$ & $41.90 \mathrm{~b}$ & $43.76 \mathrm{~b}$ \\
\hline \multirow[t]{2}{*}{ MAP-2 } & 39.21 & $42.69 \mathrm{~b}$ & $42.68 \mathrm{~b}$ & $42.53 \mathrm{~b}$ \\
\hline & \multicolumn{4}{|c|}{ Chroma } \\
\hline Control & 48.05 & $36.39 \mathrm{~b}$ & $37.71 \mathrm{~b}$ & $36.94 \mathrm{~b}$ \\
\hline Aloe vera & 48.05 & $45.12 \mathrm{a}$ & $47.15 \mathrm{a}$ & $44.27 \mathrm{a}$ \\
\hline MAP-1 & 48.05 & $44.11 \mathrm{a}$ & $45.09 \mathrm{a}$ & $42.26 \mathrm{a}$ \\
\hline \multirow[t]{2}{*}{ MAP-2 } & 48.05 & $45.66 \mathrm{a}$ & $41.86 \mathrm{a}$ & $43.79 \mathrm{a}$ \\
\hline & \multicolumn{4}{|c|}{ Hue angle } \\
\hline Control & 35.65 & $51.05 \mathrm{a}$ & $44.46 \mathrm{a}$ & $41.65 \mathrm{a}$ \\
\hline Aloe vera & 35.65 & $39.73 \mathrm{~b}$ & $35.92 \mathrm{~b}$ & $36.75 b$ \\
\hline MAP-1 & 35.65 & $36.66 \mathrm{~b}$ & $37.21 \mathrm{~b}$ & $39.69 \mathrm{~b}$ \\
\hline MAP-2 & 35.65 & $38.11 \mathrm{~b}$ & $37.66 \mathrm{~b}$ & $35.25 \mathrm{~b}$ \\
\hline
\end{tabular}

Means in columns with the same letter do not differ according to Tukey's test at $\mathrm{P}<0.05$.

MAP and AV treatments change the atmosphere around the fruit and reduce gas permeability. Thus, the increase in carbondioxide concentration, chlorophyll breakdown and delay in carotenoid synthesis ultimately are retarded change in fruit skin and flesh color Ergun and Satici (2012).

As a result, it revealed that $\mathrm{AV}$ and MAP treatments could be used as a tool to maintain quality of cornelian cherry fruits during cold storage.

\section{References}

Aglar, E., Yıdız, K., Long, L.E., 2016. The Effects of rootstocks and training systems on the early performance of '0900 Ziraat' sweet cherry. Notulae Botanicae Horti Agrobotanici Cluj-Napoca, 44(2): 573-578.

Aglar, E., Ozturk, B., Guler, S.K., Karakaya, O., Uzun, S., Saracoglu, O., 2017. Effect of modified atmosphere packaging and 'Parka' treatments on fruit quality characteristics of sweet cherry fruits (Prunus avium L. '0900 Ziraat') during cold storage and shelf life. Scientia Horticulturae, 222: 162-168.

Arowora, K.A., Williams, J.O., Adetunji, C.O., Fawole, O.B., Afolayan, S.S., Olaleye, O.O., Adetunji, J.B., Ogundele, B.A., 2013. Effects of aloe vera coatings on quality characteristics of oranges stored under cold storage. Greener Journal of Agricultural Sciences, 3(1): 39-47.

Asghari, M., Ahadi, L., Riaie, S., 2013. Studied on effect of salicylic acid and edible coating based aloe vera gel treatment on storage life and postharvest quality of grapes (Vitis vinifera L. cv. Gizel Uzum). International Journal of Agriculture and Crop Sciences, 5(2)3: 2890-2898.
Cantin, C.M, Crisosto, C.H., Day, K.R., 2008. Evaluation of the effect of different modifiedatmosphere packaging box liners on the quality and shelf life of 'Friar' plums. Hort Technology, 18: 161-165.

Carrillo-Lopez, A., Ramirez-Bustamante, F., Valdez-Torres, J., Rojas-Villegas, R., Yahia, E., 2000. Ripening and quality changes in mango fruit by coating with an edible film. Journal of Food Quality, 23(5): 479-486.

Diaz-Mula, H.M., Serano, M., Valero, D., 2012. Alginate Coatings Preserve Fruit Quality and Bioactive Compounds during Storage of Sweet Cherry Fruit. Food and Bioprocess Technology 5(8):1-8.

Dinda, B., Kyriakopoulos, A.M., Zoumpourlis, V., Thomaidis, N.S., Velegraki, A, Markopoulos, C., Dinda, M., 2016. Cornus mas L. (cornelian cherry), an important European and Asian traditional food and medicine: Ethnomedicine, phytochemistry and pharmacology for its commercial utilization in drug industry. Journal of Ethnopharmacology, 193: 670-690.

Ergun, M., F. Satici., 2012. Use of Aloe vera gel as biopreservative for 'Granny Smith' and 'Red Chief'apples. The Journal of Animal and Plant Sciences, 22(2): 363-368.

Erkan, M., Eski, H., 2012. Combined treatment of modified atmosphere packaging and 1-methylcyclopropene improves postharvest quality of Japanese plums. Turkish Journal of Agriculture and Forestry, 36: 563-575

Fischer, RL., Bennett, AB., 1991. Role of cell wall hydrolases in fruit ripening. Annual Review of Plant Physiology and Plant Molecular Biology, 4: 675703.

Giacalone, G., Chiabrando, V., 2013. Modified atmosphere packaging of sweet cherries with biodegradable 
films. International Food Research Journal, 20: 1263-1268.

Guerra, M., Casquero, P.A., 2008. Effect of harvest date on cold storage and postharvest quality of plum cv. Green Gage. Postharvest Biology and Technology, 47(3): 325-332.

Guillen, F., Diaz-Mula, H.M., Zapata, P.J., Valero, D., Serrano, M., Castillo, S., Martinez-Romero, D., 2013. Aloe arborescens and Aloe vera gels as coatings in delaying postharvest ripening in peach and plum fruit. Postharvest Biology and Technology, 83: 5457.

Kaynas, K., Sakaldas, M., Yur. M., 2010. The effects of different postharvest applications and different modified atmosphere packaging types on fruit quality of 'Angeleno' plums. Acta Horticulturae, 876: 209-216.

Khan, A.S., Sing, Z., 2008. 1-Methylcyclopropene Application and Modified Atmosphere Packaging Affect Ethylene Biosynthesis, Fruit Softening, and Quality of 'Tegan Blue' Japanese Plum During Cold Storage. Journal of the American Society for Horticultural Science, 133(2): 290-299.

Kucharska, A.Z., Soko-Letowska, A., Piorecki, N., 2011. Morphological, physical and chemical, and antioxidant profiles of polish varieties of cornelian cherry fruit (Cornus mas L.). Zywnosc, Nauka, Technologia, Jakosc, 3(76): 78-89.

Kucharska, A.Z., 2012. Active compounds of cornelian cherry fruit (Cornus mas L.). Wydawnictwo Uniwersytetu Przyrodniczego Wroclaw.

Lazan, H., Alid, M., Selamat, M.K., 1993. The underlying biochemistry of the effect of modified atmosphere and storage temprature on firmness decrease in papaya. Acta Horticulturae, 343: 141-147.

Lurie, S., Pesis, E., Gadiyeva, O., Feygenberg, O., Ben-Arie, R., Kaplunov, T., Zutahy, Y., Lichter, A., 2006. Modified ethanol atmosphere to control decay of table grapes during storage. Postharvest Biology and Technology, 42: 222-227

Moreira, M.R., Pereda, M., Marcovich, N.E., Roura, S.I., 2011. Antimicrobial effectiveness of bioactive packaging materials from edible chitosan and casein polymers: assessment on carrot, cheese, and salami. Journal of Food Science, 76(1): 54-63.

Navarro, D., Diaz-Mula, H.M., Guillen, F., Zapata, P.J., Castillo, S., Serrano, M., Valero, D., MartínezRomero, D., 2011. Reduction of nectarine decay caused by Rhizopus stolonifer, Botrytis cinerea and Penicillium digitatum with Aloe vera gel alone or with the addition of thymol. International Journal of Food Microbiology, 151(2): 241-246
Ochiki, S., Wolukau, N.J.,Gesimba. R.M., 2014. Effect of aloe vera coating on postharvest quality and shelf life of mango (Mangifera indica L.) fruits CV. 'Ngowe'. African jouranal of Biotechnology, 13(36): 37243729.

Ozturk, B., Bektas, E., Aglar, E., Karakaya, O., Gun, G., 2018. Cracking and quality attributes of jujube fruits as affected by covering and pre-harvest Parka and GA3 treatments. Scientia Horticulturae, 240: 65-71.

Padmaja, N., John Don Bosco, S., 2014. Preservation of jujube fruits by edible Aloe vera gel coating to maintain quality and safety. Indian Journal of Science Research and Technology. 2(3): 79-88.

Peano C., Girgenti, V., Sottile, F., Giuggioli., N.R., 2010. Improvment of plum storage with modified atmosphere packaging. Acta Horticulturae, 876: 183188.

Remon, S., Venturini, M.E., Lopez-Buesa, P., Oria, R., 2013. Burlat cherry quality after long range transport, I optimisation of packaging conditions. Innovative Food Science and Emerging Technologies, 4: 425434.

Serrano, M., Valverde, J. M., Guillén, F., Castillo, S., MartínezRomero, D., Valero, D., 2006. Use of Aloe vera gel coating preserves the functional properties of table grapes. Journal of Agricultural and Food Chemistry, 54(11): 3882-3886.

Singh, S.P., Rao, D.V.S., 2005. Effect of modified atmosphere packaging (MAP) on the alleviation of chilling injury and dietary antioxidants levels in 'Solo' papaya during low temperature storage. European Journal of Horticultural Science, 70: 246-252.

Sogvar, O.B., Saba, M.K., Emamifar, A., 2016. Aloe vera and ascorbic acid coatings maintain postharvest quality and reduce microbial load of strawberry fruit. Postharvest Biology and Technology, 114: 29-35.

Sottile, F., Peano, C., Giuggioli, N.R., Girgenti, V., 2013. The effect of modified atmosphere packaging on the physical and chemical quality of fresh yellow plum cultivars. Journal of Food, Agriculture and Enviroment, 11:363-367.

Sumnu, G., Bayindirli, L., 1995. Effects of coatings on fruit quality of amasya apples. Food Science and Technology, 28(5): 501-505.

Valero C., Crisosto, C.H., Slaughter, D., 2007. Relationship between non-destructive firmness measurements and commercially important ripening fruit stages for peaches, nectarines and plums. Postharvest Biology and Technology, 44: 248-253.

Valero, D., Mirdehghan, S.H., Sayyari, M., Serrano, M., 2014. Vapor treatments, chilling, storage, and antioxidants in pomegranates. In: Preedy, V.R. (Ed.), Processing 
and Impact on Active Components in Food. Academic Press, London, pp. 189-196.

Valverde, J.M., Valero, D., Romero, D.R., Guillean, F.N., Castillo, S., Serrano, M., 2005. Novel edible coating based on aloe vera gel to maintain table grape quality and safety. Journal of Agricultural and Food Chemistry, 53: 7807-7813.

Vieira, J.M., Flores-Lopez, M.L., De Rodrigez, D.J., 2016. Effect of chitosan-Aloe vera coating on postharvest quality of blueberry (Vaccinium corymbosum) fruit Postharvest Biology and Technology, 116: 88-97.

Zapata, P., Navarro, D., Guillén, F., Castillo, S., MartínezRomero, D., Valero, D., Serrano, M., 2013. Characterisation of gels from different Aloe spp. as antifungal treatment: Potential crops for industrial applications. Industrial Crops and Products, 42: 223-230. 